\title{
The Aerodynamics of the Wavy Blade Under the Effect of Fluctuated Wind Flow
}

Basim A. R. Al-Bakri

Lecturer

Department of Aeronautical Engineering College of Engineering University of Baghdad Aljadriya, Baghdad

Radwan M. Aljuhashy

Lecturer

Department of Mechanical Engineering College of Engineering Wasit University Kut, Wasit

In the present study, the influence of the wavy edge blade on aerodynamic characteristics for the flow of blades at Reynolds number (Re) of $8 \times 10^{5}$ is numerically investigated based on the unsteady wind flow. Aerodynamic characteristics of a (sinusoidal leading edge) wavy NACA0015 aerofoil blade are carried out using ICEM 19.1 and ANSYS fluent. The numerical simulation is conducted then validated by experimental data with steady wind flow. This is conducted by employing the same Reynold's number in the experimental work. While, the unsteady flow was numerically performed at $1 \mathrm{~Hz}$ frequncy of wind flow conditions. The main findings from this work show that the wavy blade can behave better in turbulent wind conditions with the maximum lift coefficient of 0.73 compared to 0.621 for the normal blade. However, the findings declare that the wavy blade stalled earlier than the normal one in the unsteady flow case. Similarly, it stalled at $12^{\circ}$ angle of attack earlier than the normal one which was stalled at $14^{\circ}$ in the steady flow case.

Keywords: wavy blade, CFD, NACA0015 aerofoil,steady flow, angle of attack and fluctuated flow.

\section{INTRODUCTION}

The need to enhance the aerodynamics of any windy shapes has been increased. This is however a demanding aim and it requires re-thinking of the way to modify these shapes. Plenty of projects have studied the shape of some animals related to the current wind machines to make these machines more competitive with that of the traditional production design.

Fish and Battle [1] were the first to explore humpback whale's ability to flip and manoeuvre by tubercles or protuberances along their leading edge. An experimental study was conducted by Miklosovic et al. [2] The blade model was NACA002 aerofoils to simulate a flipper and the Reynolds number was around $5 \times 10^{5}$. A delayed separation and increasing lift was found. The modified model showed lift to drag ratio $\left(\mathrm{CL} / \mathrm{C}_{\mathrm{D}}\right)$ better than or equal to the ratio of the normal model. However, it was low between 10 and 12 degrees. Watts and Fish [3] performed a simulation study to mimic the flow over a bumped wing and normal one at high Reynolds numbers and various AOA. The study declared that there was an enhancement in performances for the bumped wing with increasing in lift to drag ratio up to $17.6 \%$. The leading-edge serration technique was used by Hansen et al. [4] and Kobæk, [5]. It was observed that the lift coefficient enhanced in the post-stall regime. Whereas, it was lower in the pre-stall zone. A numerical study was performed by Zhang and $\mathrm{Wu}[6]$ to investigate the performances of the wavy NREL Phase-VI

Received: December 2020, Accepted: April 2021

Correspondence to: Dr Basim A. R. Al-Bakri

University of Baghdad, Department of Aeronautical

Engineering, Baghdad, Iraq

E-mail: b.rasheed@coeng.uobaghdad.edu.iq

doi:10.5937/fme2103704A

(C) Faculty of Mechanical Engineering, Belgrade. All rights reserved rotor. In comparison with a normal leading-edge blade, the values of the shaft torque of the fluctuated leadingedge blade were high at high speeds $\leq 15 \mathrm{~m} / \mathrm{s}$. That means that the fluctuated leading-edge blades could develop the aerodynamic characteristics at high wind speed. In contrast, the study also showed the new shape lowered the stall point for the wind turbine rotor at the rated wind speed $10 \mathrm{~m} / \mathrm{s}$. The power performance of a vertical wind turbine (VAWT) operating at low TSRs was numerically investigated by Wang and Zhuang [7]. The sinusoidal leading-edge blade of NACA0018 aerofoils was implemented in thier study. The main finding was that the maximum lift coefficient improved 25\% higher than that in the standard model. This means that the new geometry of the blades can harvest wind energy more than the base model specially at low TSRs. A vertical wind turbine which was based on three NACA0022 blades with conditions of the unsteady wind inside a wind tunnel was experimented. The Reynolds number up to 50,000 with $7 \%$ and $12 \%$ fluctuated wind conditions at $0.5 \mathrm{~Hz}$ of a frequency were utilised. The unsteady power coefficient $(\mathrm{Cp})$ with $7 \%$ fluctuated wind velocity had roughly the same value as to that value from the steady wind state. Whereas at the $12 \%$ fluctuated wind velocity, there was a noticeable decline in the average $\mathrm{Cp}$. A wavy blade geometry was numerically studied and compared with it S809 aerofoil baseline. The findings showed that the wavy blade stalled at low angles of attack, so the harvested lift was low.

Z. Čarija et al [8] studied a sinusoidal shape leading edge of the NACA0012 then compared it with a normal one utilised a Reynolds number of $1.8 \times 10^{5}$. The wavy blade showed up to $50 \%$ higher lift to drag ratio over a range AOA than the normal blade.

David Wekesa et. al [9] numerically investigated the influence of the operating conditions on the vertical axis 
wind turbine (VAWT) of NACA00XX symmetric air foils with $12 \%$ and $22 \%$ thickness in unsteady wind conditions. Three unsteady wind simulations were accomplished. the results showed that the fluctuating of free stream wind speed and blade thicker were more essential in operating VAWT.

Zhang et. al [10] investigated an active control strategy for blade in wind turbine at off-design conditions. They introduced a series of small flat wings with delta shape in order to generate an enhanced vortex at the leading edge of the blade. Their results showed that about $20 \%$ enhancement of the wind turbine shaft torque at the stall was achieved when using the active controlled leading edge. The authors claimed that the adoption of the active control leading edge was desirable because they can produce more stable and controllable output power for all operating conditions.

Lynch and Smith [11] experimentally studied the unstructured over set incompressible CFD simulations of wind turbine using a hybrid RANS/LES turbulence model. A correlated model was predicted.

Scheurich and Brown [12] experimentally studied the steady rotors effect on the performance of vertical axial wind turbine. The vorticity transport model was utilized to comprehend the aerodynamic performance and wake dynamics of the steady and unsteady wind velocity. Three different vertical axis wind turbine blades were examined: straight-blade, curved-blade, and helically twisted-blade. In unsteady wind conditions the non-twisted blades were produced less efficacy.

Wu et. al [13] theoretically studied the gust effect on the operation of wind turbine. The influence of sinusoidal gusts on a three-bladed vertical axis wind turbine were investigated. The gusts parameters of gust direction, velocity amplitude, and frequency were considered. The chimera mesh technique resolved a gust approach model of the real rotation of the rotor were utilized. The findings were claimed important to understand the gust influence in field site selection.

Data form subsonic wind tunnels must to be analysed to gain the highest level of acceptability. This could be conducted by repeated the steps of work, as mentioned in Ocokoljic et al [14] [15]. Furthermore, a study conducted by Rasuo [16] [17] provided a good indication of aerodynamic tests in $2 \mathrm{D}$ conditions of flow. Additionally, the effect of Reynolds number on the solid and flow blockage was investigated.

In the present study, the sinusoidal wave technique is selected and employed on the leading-edge of a NACA0015 aerofoils blade. To the best knowledge of the authors, there is no focusing on the effect of the fluctuated flow (real wind conditions) on a blade with this technique. So that, there is a comparison with the normal blade model to gain further insight into the aerodynamics of this type of the blade under unsteadiness flow conditions.

\section{METHOLODOGY}

\subsection{Experimental set up}

The experimental work was carried out to verify the CFD model for the case of steady state wind velocity with both the normal blade and the blade with sinusoidal leading edge were examined. Once the CFD model was validated for the steady wind flow conditions, the present unsteady CFD model was considered trusted to investigate the behaviour of the NACA0015 blade with normal and sinusoidal leading edge. This verification strategy was adopted because it was hard to achieve the unsteady wind flow conditions due to the limitation of the available wind tunnel. The lift and drag forces at various angles of attack of a NACA0015 blade were experimentally investigated in a wind tunnel. The subsonic open cycle wind tunnel has ability to generate wind speed reach to $(22 \mathrm{~m} / \mathrm{s})$ and unsteady gust $+/-15 \%$ at $10 \mathrm{~m} / \mathrm{s}$ at $2 \mathrm{~Hz}$ with a fan set up at the outlet. The test section was $1.2 \mathrm{~m} \times 1.2 \mathrm{~m}$ cross section and $2.4 \mathrm{~m}$ depth. At the inlet of the tunnel, a honeycomb structure could deliver $1 \%$ turbulence intensity, which was the ratio of standard deviation of fluctuating wind velocity to the mean flow velocity. A maximum wind speed in the test section of $25 \mathrm{~m} / \mathrm{s}$ could be given by an electric motor.

The dimensions of the normal blade were: $0.7 \mathrm{~m}$ length and $0.2 \mathrm{~m}$ cord. The same dimensions would also have the wavy blade with a sinusoidal shape at the leading edge. The effect of the blade holder and blockage were very small so, they were neglected.The shape of the studied blade was rectangular (a $700 \mathrm{~mm}$ span and a 195 $\mathrm{mm}$ chord) with a NACA 0015 profile. The $3 \mathrm{~mm}$ of the blade cord was removed by trimming the trailing edge to avoid the skewness cells through the mesh.
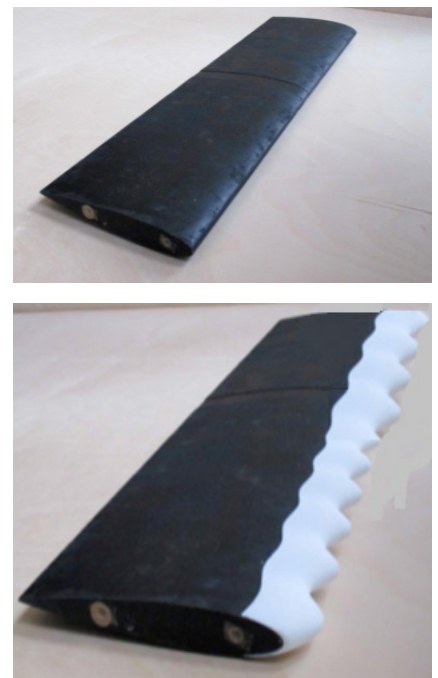

Figure 1. Overview of the experimental blades, the normal blade (up) and wavy blade (down).

The blade was made of medium-density fibreboard (MDF) wood and it was painted to lessen the roughness on the surface area, see Figure 1. This could give a shape close to reality then getting the measured results closer to the simulated results. The blade was set up inside the test section and mounted on a turning recording device to adjust the angle of attack AOA. The forces were measured by the gauges which were displayed on a computer using LabVIEW software. By causing a pressure difference, on the Pitot probe, which was faced the inlet flow, was converted into velocity by a FCO510 Micro-manometer. The gauges can sense forces, which were displayed on a computer using LabVIEW software. Then coefficients were calculated in an excel spreadsheet. 


\section{NUMERICAL SOLUTIONS}

\subsection{Independent case study}

A 2D simple case numerical study, for a NACA0012 aerofoil, was conducted and validated by experimental data of Ladson [18]. The NACA0012 aerofoil was chosen due to its high similarity to a NACA0015 profile. The reason of adopting the case study is to examine the adequateness of cells around aerofoils then blades This was accomplished with the same boundary conditions as Re which was lower than $0.75 \times 10^{6}$ with a gradual increase in (AOA). A generated unstructured mesh around the NACA0012 was applied to simulate an incompressible turbulent flow. Many cells as (200, 350 and 600 cells) which were set up around the blade. The $\mathrm{k}-\omega$ SST turbulence model was used due to its accuracy in case of the turbulent flow in order to capture the aerodynamics on the first layers that will be close to the surfaces of the blade [19]. Furthermore, the boundary conditions that experimentally used, were again applying. Many of iterations of the solution were done until it reached the convergence.

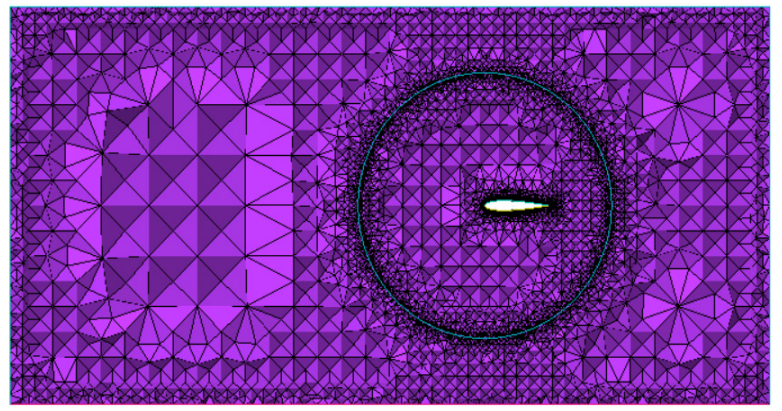

Figure 2. The cut plan of the mesh domain.

The findings show that lift and drag coefficients $\left(\mathrm{C}_{\mathrm{L}}\right)$ and $\left(\mathrm{C}_{\mathrm{D}}\right)$ respectively, can match their experimental counterpart at many AOA from $\left(-10^{\circ}\right.$ to $\left.20^{\circ}\right)$. There are, however, small differences at high attack angles $\left(17^{\circ}\right.$ and $18^{\circ}$ ) when the flow may separate at these values. The experimental and CFD results are almost homologous due to the flow probably is stalled except for the simulation the 600 cells. With 600 cells, there is a sudden fluctuated in the solution which may occur because of high numbers of cells with the turbulent flow, see Figure 2. In addition, there is an obviously divergence between the $\left(C_{L}\right.$ and $\left.C_{D}\right)$ especially at stall angle that may occur because of the effect of the roughness of the aerofoil surface.

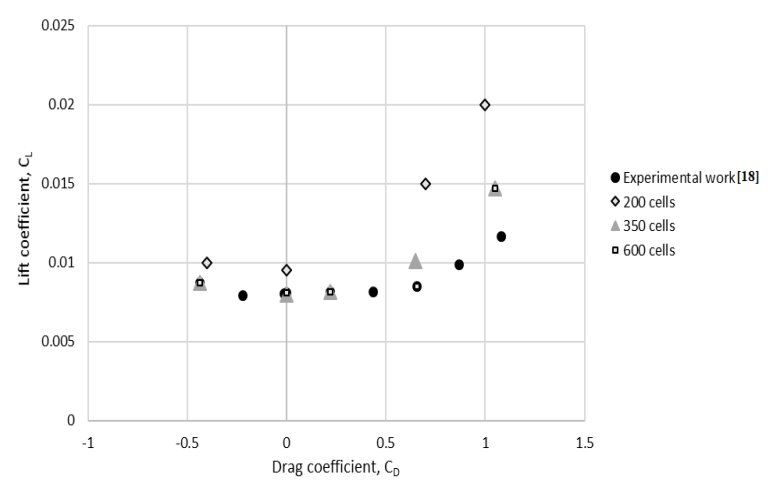

Figure 3. Suitability of cells around the cross-section of a blade.
To sum up, the solutions with 200, 350 and 600 cells around blades show an acceptable trend with that of the experimental work. The angle of attack that makes aerofoil stall is around $\left(17^{\circ}\right)$ with those cells at the same Re. Further increasing in the number of cells shows no more converging with the experimental work. Therefore, 350 cells are probably considered sufficient for the current study.

\subsection{Blade geometry and mesh generation}

The modified NACA0015 aerofoils blade wavelengths (x) is 0.4 from the chord length (c), when the chord length is $0.2 \mathrm{~m}$ that is highly similar to the previous case studies [1] and [8], as shown in Figure 4.

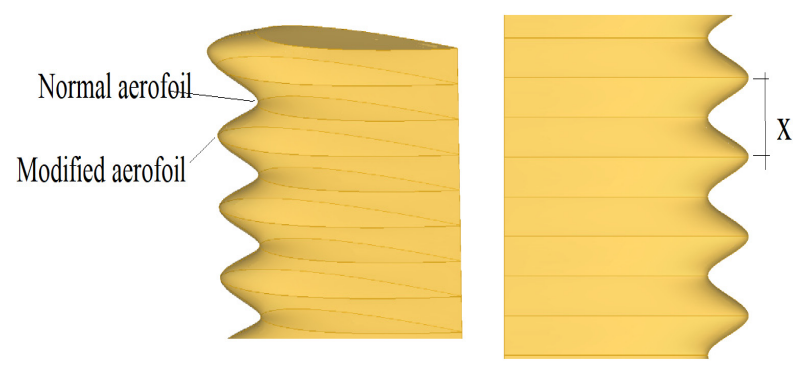

Figure 4. Sinusoidally shaped blade geometry showing wave length.
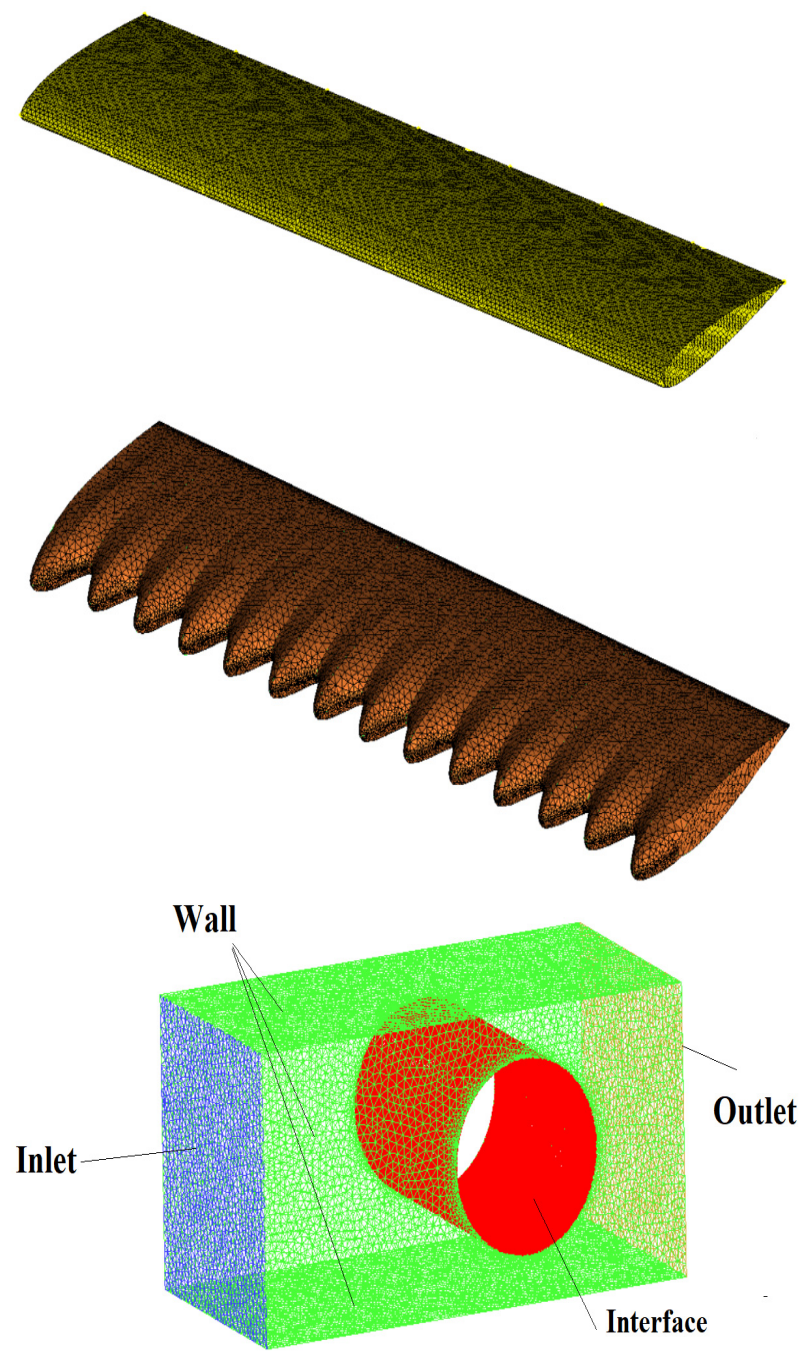

Figure 5. Two different blade geometries based on the NACA0015 aerofoil blade (up) and the test section (down). 
The NACA0015 aerofoils 3D blade was simulated with an experimental work of the wind tunnel model. In the experimental work, a blade of NACA0015 aerofoils was placed in the test section, approximately $1.5 \mathrm{~m}$ from the entrance to the test section. Two cases of the test section were studied; normal and wavy leading-edge blade, Figure 4 . The total number of cells that used was up to $2.5 \times 10^{6}$ nodes including 350 nodes were around the blade's surface with the influent turbulence model (k- $\omega$ SST) and time step size $8.3 \times 10^{-3}$ second. The results were taken by making an interface between the surface of the block and the whole mesh of the test section. The main purpose behind that interface was to rotate the blade at variant angle of attacks without changing the wind velocity directions at each angle. Then, both cases (steady and unsteady wind flow) were run in Ansys Fluent software so as to mimic the experimental work in the wind tunnel.

\section{STEADY FLOW SIMULATION}

From Figure 6, there are generally acceptable agreements between the lab data and the Fluent model findings for the NACA0015 aerofoils blade. However, there is an apparent discrepancy between whole curves. Probably, neglecting the effect of the blade support mechanism on the pressure side (bottom) of the blade led to generating high pressure then slightly high lift force than the CFD results. Moreover, the roughness of the blade's surface is not modelled that could lead to slightly high drag force with the rough surface. The angle that the blade stalled entirely is roughly the same for two curves at $14^{\circ}$ with the normal blade.

The wavy blade displays similar trend to the previous blade. However, the two curves stall early at $12^{\circ}$ and showed equal or slightly less lift than normal blade. In short, this case study could pave the way for the next case by exposing blades to the real boundary condition using just the numerical solution.

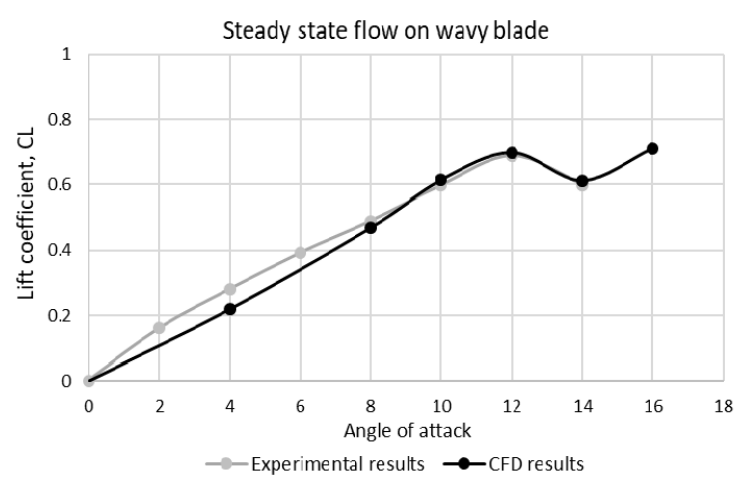

Figure 6. The aerodynamic characteristics of both blades at steady flow conditions.

\section{UNSTEADY FLOW SIMULATION}

The previous boundary conditions and the same turbulence model is also used here with this case. Nevertheless, the sinusoidal shape wind speed will hit the wind machine. The sinusoidal incoming wind speed is achived using a user defined function (UDF) file. The UDF file is a code that is written in the $\mathrm{C}$ programming language.
Oscillations is employed numerically with period of fluctuation and at average wind flow using equation 1 which were applied by [19] and [20]:

$$
V_{(t)}=\bar{U}+\text { Amplitude } \sin (2 f \pi t)
$$

where $\mathrm{V}_{(\mathrm{t})}$ is an instantaneous wind velocity in $\mathrm{m} / \mathrm{sec}, \overline{\mathrm{U}}$ is the average velocity in $\mathrm{m} / \mathrm{sec}, f$ is wind flow frequency in $\mathrm{Hz}$ and $\mathrm{t}$ is the flow time in second. Amplitude refers to the highest or the lowest value of the fluctuated wind can be observed.

The average velocity is $6 \mathrm{~m} / \mathrm{sec}$ with SST model to mimic the weather condition in some regions in the world and where the maximum power could obtain [21-23]. This instantaneous wind speed value is used in UDF to produce the sinusoidal wind flow. UDF is a code file which was written with $\mathrm{C}$ language is used to control the wind oscillations. Then, it employed in Flu-ent to simulate the starting behaviour of the inlet wind flow. Wickins and McIntosh [20] assumed that $1 \mathrm{~Hz}$ is the top frequency of the fluctuations in wind speed according to experimental data in an urban area. Therefore, the unsteady wind flow had amplitude of $25 \%$ of the mean velocity.
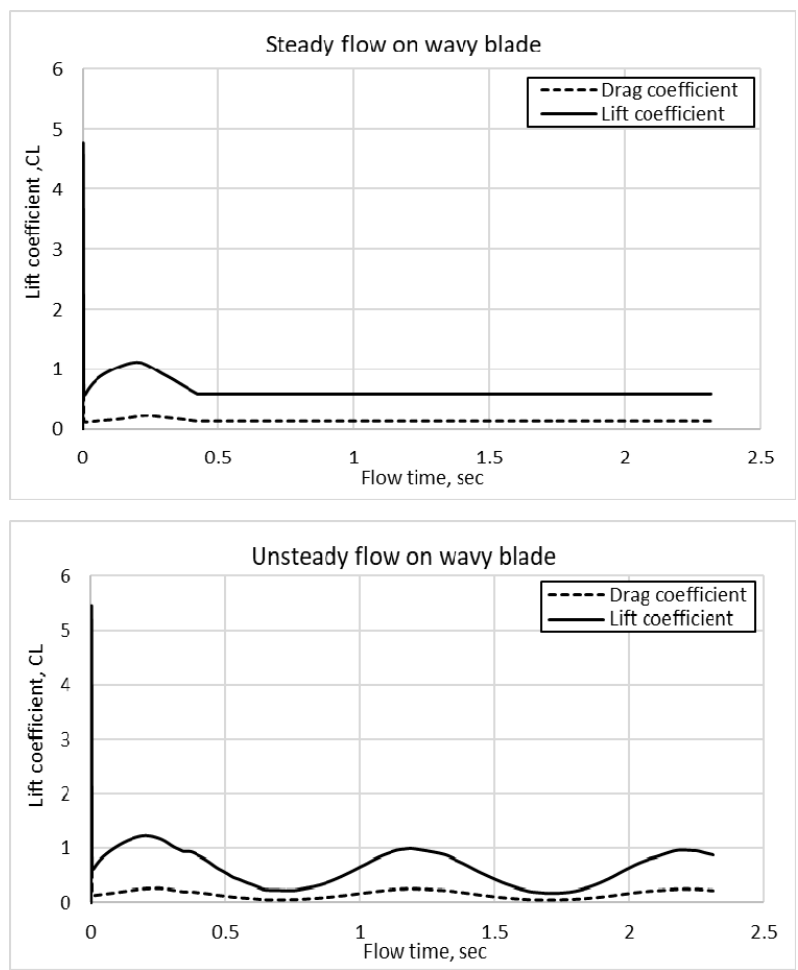

Figure 7. Lift coefficient history at $A O A=12^{\circ}$ for the steady and unsteady wind cases.

\section{RESULTS AND DISCUSSIONS}

For the wavy blade and for both cases of steady and unsteady wind flow conditions, the evolution of the lift coefficient begins at low angles of attack. A linear evolution initiates from $0^{\circ}$ then it suddenly drops due to stall at after $8^{\circ}$ AOA. The lift is then fluctuated. This could mean that the drag force slightly increases before and at the stall angle. The increase of drag force may go much faster after stall, as shown in Figure 8.

The presence of the wavy leading edges on the blade at unsteady wind flow can obviously increase the lift 
force and delay the stall at $8^{\circ} \mathrm{AOA}$ rather than about $11.5^{\circ} \mathrm{AOA}$ at the normal one. The configuration with normal leading edge provides lower lift than the wavy blade specially at unsteady wind flow. However, the drop in lift coefficient at stall may have little importance in considerations and after the stall point it keeps increasing.

The lift and drag coefficients $\left(\mathrm{C}_{\mathrm{L}}\right.$ and $\left.\mathrm{C}_{\mathrm{D}}\right)$ at any angles of attack can be determined, using the following equations, which vary as the square of incoming wind speed V:

$$
\begin{aligned}
& \mathrm{L}=0.5 \rho \mathrm{V}^{2} A \mathrm{C}_{\mathrm{L}} . \\
& \mathrm{D}=0.5 \rho \mathrm{V}^{2} A \mathrm{C}_{\mathrm{D}},
\end{aligned}
$$

where $\mathrm{L}$ and $\mathrm{D}$, are lift and drag forces in Newton, $\rho$ is the density of the air in $\mathrm{kg} / \mathrm{m}^{3}, \mathrm{~A}$ is the area of the blade in $\mathrm{m}^{2}$.

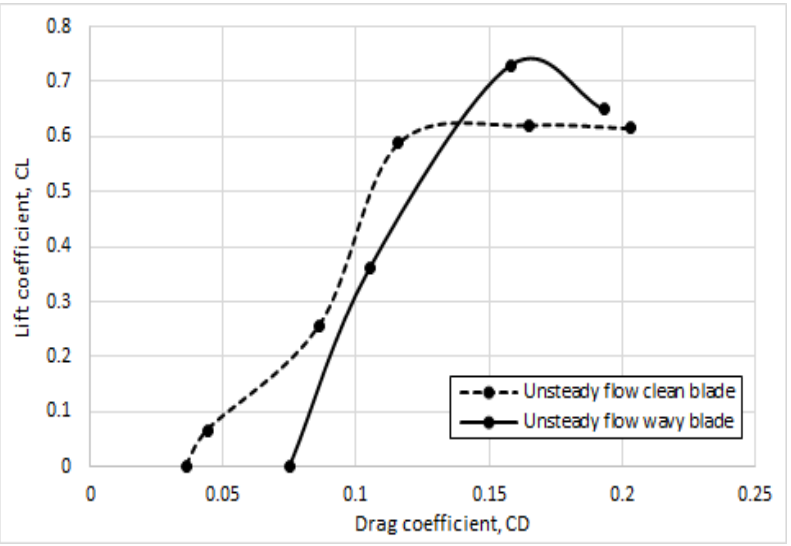

Figure 8. The aerodynamic characteristics of both blades at unsteady flow conditions.

In comparison with the wavy blade, the normal blade has a lower lift, except a small regain before stall, at all drag coefficients, as shown in Figure 8. Moreover, the normal blade shows an earlier stall at 0.1 drag coefficient then raises up at 0.17 drag coefficient and as its lift force keeps increasing after this value due to the reattached action of the flow above the blade. This could indicate that the wavy blade can perform better under unsteady wind flow conditions. Snapshots of the pitching aerofoil unsteady flow at different AOA are introduced in the following figures.

Figure 9 and Figure 10, display the streamlines of the unsteady flow and static pressure contours on the suction side of the blades for various angles of attack. Figure 9, it can be observed that the pressure in the front of the suction side of the blade is lower than on the back along to the span-wise locations at all AOA. Moreover, the flow is reattached on the surface again, so the lift raises up. It is found that at $0 \mathrm{AOA}$, the flow is completely attached on the surface of the blade where no stall effects, as show in Figure 10. At 6 and above, it behaves fine although the blade is stalling near the root of the blade where the blade still has lower angle of attack. At 12 AOA case, the blade is completely stalled so it has poor lift force. Swirling air flow originates at the surface of the blade because of the strong stall. The air flow moves back towards the leading edge that could mean the blade is in the separation shear layer.

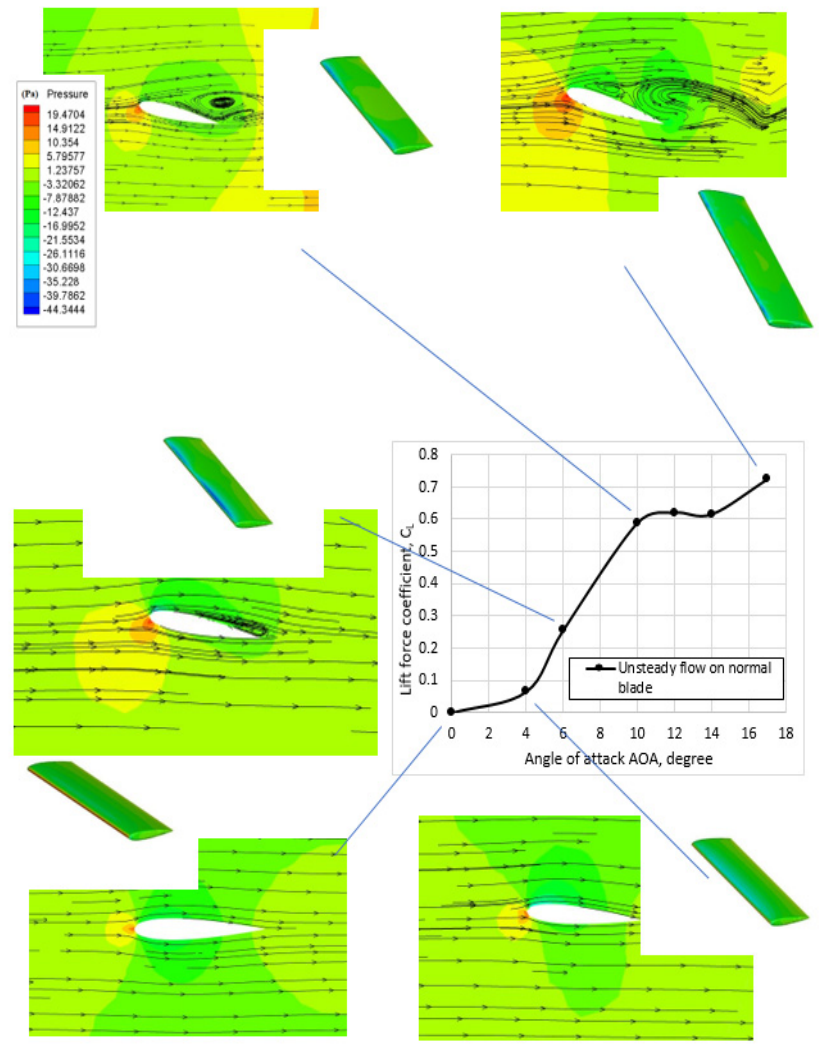

Figure 9. A contour plot showing the streamlines for different angles of attack at normal blade.
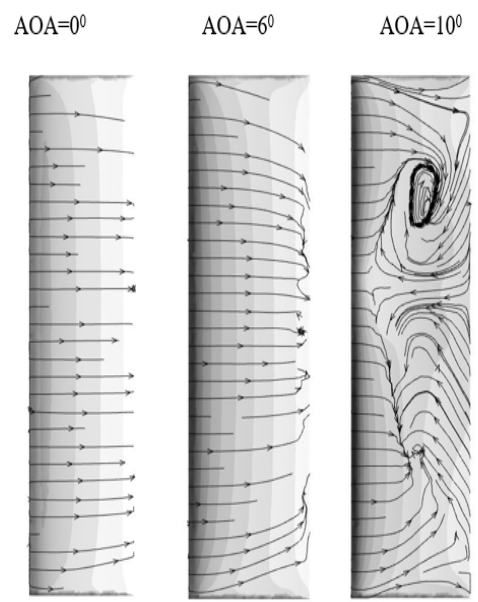

$\mathrm{AOA}=12^{0}$

Figure 10. Streamlines for different angles of attack at the suction side of the normal blade.

Figure 11, demonstrates that vortices occur on the trailing edge when the AOA is increased to $8^{\circ}$. Furthermore, the separation point on the surface of the aerofoil travels forward to the leading edge at $12^{\circ}$. In contrast, on the trailing edge of the aerofoil, at low AOAs, there is no separated flow at all.

Figure 12, displays that the streamlines on the suction side of the blade at 0 AOA, the flow is completely attached on the surface of the blade similar to that from normal blade. However, at $8^{\circ}$ and above, the blade is stalling near the trailing edge (root), this declares that the wavy blade stalls earlier than the normal one. At 10 AOA case, the blade is completely stalled, as streamlines shown, so it has poor lift force. 


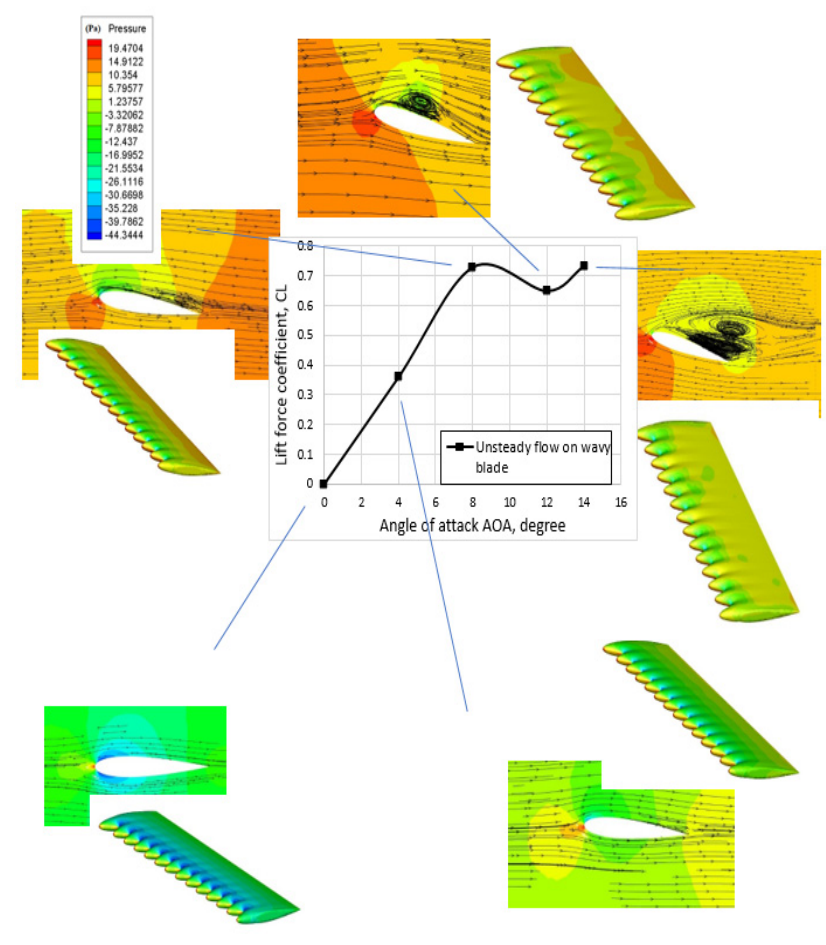

Figure 11. A contour plot showing the streamlines for different angles of attack at wavy blade.

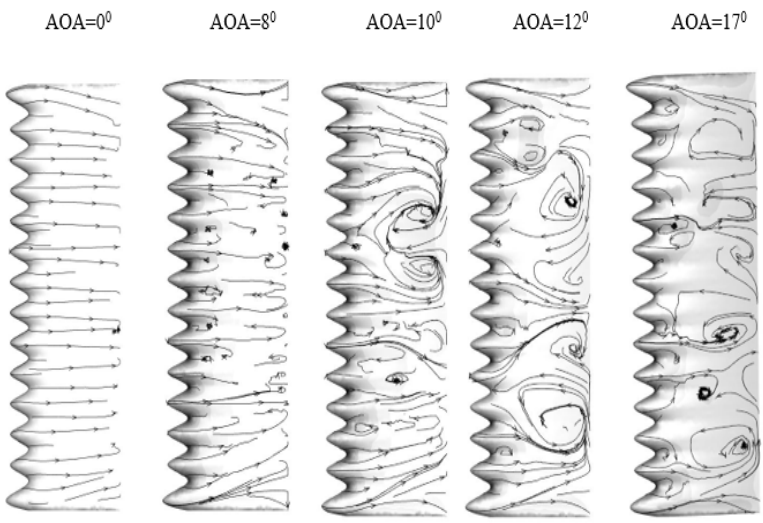

Figure 12. Streamlines for different angles of attack at the suction side of the wavy blade.

\section{CONCLUSION}

The aerodynamic of the span-wise NACA0015 aerofoil blades with and without wavy leading edge design were examined under steady and unsteady wind conditions. With the wavy leading edge, blades can generate a better lift (0.73) and the delay in stall is much important than with a normal leading edge which shows 0.62 lift coefficient. Although the normal blade at steady flow showed high lift force, it demonstrated lower lift at unsteady flow. All in all, the wavy modification could have a positive effect on the lift generation of the blade specially on the real wind conditions.

\section{ACKNOWLEDGMENT}

The authors would like to express their gratitude to the colleges of Engineering at University of Baghdad and Wasit University for their encouragement during the completion of this work.

\section{REFERENCES}

[1] Fish, F.E. and Battle, J., "Hydrodynamic design of the humpback whale flipper", Journal of Morphology, vol. 225, nr.1 pp.51-60, 1995.

[2] Miklosovic, D.S., Murray, M.M., Howle, BLADE, Fish, F.E., "Leading-edge tubercles delay stall on humpback whale (Megaptera novaeangliae) flippers", Physics of Fluids, vol. 16, nr.5, 2004.

[3] Watts, P., Fish, F.E. "The influence of passive, leading edge tubercles on wing performance", Proceedings of the 12th International Symposium on Unmanned Untethered Submersible Technology, UUST01, Autonomous Undersea Systems Institute, Durham, NH, 2001.

[4] Hansen KL, Kelso RM, Dally BB. Performance variations of leading-edge tubercles for distinct airfoil profiles. AIAA J 2011;49:185-94.

[5] Kobæk, C. M., and Hansen, M. O. L. (2016). Numerical study of Wavy Blade Section for Wind Turbines. Journal of Physics: Conference Series (Online), 753. IOP Publishing.

[6] Zhang R. K. and Wu J. Z., Aerodynamic characteristics of wind-turbine blades with a sinusoidal leading-edge, to appear in Wind Energy, 2011 John Wiley \& Sons, Ltd.

[7] Wang, Z., \& Zhuang, M. (2017). Leading-edge serrations for performance improvement on a vertical-axis wind turbine at low tip-speed-ratios. Applied Energy, (June), 0-1.

[8] Maruši, Z. C. E., Novak, Z., \& Fu, S. (2014). Numerical analysis of aerodynamic characteristics of a bumped leading edge turbine blade, Engineering Review 34(2), 93-101.

[9] Wekesa, D. W., Wang, C., Wei, Y., \& Danao, L. A. M. (2014). Influence of operating conditions on unsteady wind performance of vertical axis wind turbines operating within a fluctuating free-stream: A numerical study. Journal of Wind Engineering and Industrial Aerodynamics, 135, 76-89.

[10] Zhang, R., Wu, J., Chen, S., \& Systems, C. (2012). A new active control strategy for wind-turbine blades under off-design conditions, Fourth International Symposium on Physics of Fluids (ISPF4) International Journal of Modern Physics: Conference Series 19, 283-292.

[11] Lynch, C. E., \& Smith, M. J. (2013). Unstructured overset incompressible computational fluid dynamics for unsteady wind turbine simulations, Wind Energy published inWiley Online Library, 1033-1048.

[12] Scheurich, F., \& Brown, R. E. (2013). Modelling the aerodynamics of vertical-axis wind turbines in unsteady wind conditions, Wind Energy published inWiley Online Library, 91-107.

[13] Wu, Z., Wang, Q., \& Bangga, G. (2020). Responses of vertical axis wind turbines to gusty winds, Journal of power and energy, 0(37), 1-13.

[14] Ocokoljic, G., Damljanovic, D., Vukovic, D., Rasuo, B.: Contemporary Frame of Measurement and Assessment of Wind-Tunnel Flow Quality in a Low-Speed Facility, FME Transactions, 46 (4): pp. 429-442, 2018. 
[15] Ocokoljić, G., Damljanović, D., Rašuo, B., Isaković, J.: Testing of a standard model in the VTI's large-subsonic wind-tunnel facility to establish users' confidence, FME Transactions 42 (3), pp. 212-217, 2014.

[16] Rasuo, B.: Scaling between Wind Tunnels-Results Accuracy in Two-Dimensional Testing, Transactions of the Japan Society for Aeronautical \& Space Sciences, Vol.55, No.2, March 2012, pp. 109-115, doi: 10.2322/tjsass.55.109.

[17] Rasuo, B.: The influence of Reynolds and Mach numbers on two-dimensional wind-tunnel testing: An experience, The Aeronautical Journal, Volume 115, Number 1166, Paper No. 3542, 2011, pp. 249-254, doi: 10.1017/S0001924000005704.

[18] Ladson , C. L. ,(1988). Effects of Independent Variation of Mach and Reynolds Numbers on the Low-Speed Aerodynamic Characteristics of the NACA 0012 Airfoil Section, , NASA TM 4074.

[19] Danao, L. A., Eboibi, O., \& Howell, R. (2013). An experimental investigation into the influence of unsteady wind on the performance of a vertical axis wind turbine. Applied Energy, 107, 403-411.

[20] Bertenyi T,Wickins C,McIntosh S. Enhanced energy capture through gust-tracking in the urban wind environment. AIAA-2010-1376. 48th AIAA Aerospace Sciences Meeting, Orlando, Florida, USA, 2010.

[21] Kavade, R.K., Ghanegaonkar, P.M.: Effect of Best Position Blade Pitching on Power Coeficient of VAWT at Different Tip Speed Ratio by SST \& DMST Model, FME Transactions, Vol. 46 No 4, pp 560-566, 2018.

[22] Biadgo, A.M., Aynekulu, G.: Aerodynamic Design of Horizontal Axis Wind Turbine Blades, FME Transactions, Vol. 45 No 4, pp 647-660, 2017.

[23] Svorcan, J., Trivković, Z, Ivanov, T., Baltić, M. and Pekovi, O..: Multi-objective Constrained Optimizations of VAWT Composite Blades Based on FEM and PSO, FME Transactions, Vol. 47 No 4, pp 887-893, 2019.

\section{NOMENCLATURE}
A Angle of the blade, $\mathrm{m}^{2}$
AOA Angle of attack, degree
$\mathrm{C}_{\mathrm{D}} \quad$ Drag force coefficient

$\begin{array}{ll}C_{L} & \text { Lift force coefficient } \\ C_{p} & \text { Power coefficient } \\ \text { 2D } & \text { Two-dimensional } \\ \text { 3D } & \text { Three-dimensional } \\ \text { Re } & \text { Reynold's number } \\ \text { UDF } & \text { User-defined function } \\ V_{(t)} & \text { Instantaneous velocity, m/s-1 }\end{array}$

\section{Superscripts}

$\begin{array}{ll}\text { D } & \text { Drag } \\ \text { L } & \text { Lift } \\ \text { T } & \text { Time, s }\end{array}$

\section{Greek symbols}

$f \quad$ Wind frequency, s-1

\section{АЕРОДИНАМИКА ТАЛАСАСТЕ ЛОПАТИЦЕ ПОД УТИЦАЈЕМ ФЛУКТУИРАЈУЋЕГ ПРОТОКА ВЕТРА}

\section{Б.А.Р. Ал-Бакри, Р.М. Аљухаши}

Нестационарно струјање ветра је представљало основу за нумеричко истраживање утицаја таласасте ивице лопатице на аеродинамичке карактеристике кретања лопатица при Рејнолдсовом броју 8 × $10^{5}$. Аеродинамичке карактеристике таласасте NACA 0015 аеропрофилне лопатице су испитане помоћу ICEM 19.1 и ANSYS fluenta. После нумеричке симулације извршена је валидација експерименталним подацима о стационарном струјању ветра. Коришћени су слични гранични услови при Рејнолдсовом броју различитих нападних углова, док је за нестационарно струјање у условима протока ветра коришћена фреквенција од $1 \mathrm{~Hz}$. Резултати показују да се таласаста лопатица понаша боље у турбулентним условима ветра са коефицијентом силе узгона од 0,73 у поређењу са 0,621 код нормалне лопатице. Али, таласаста лопатица се зауставила пре нормалне лопатице код нестационарног протока. Слично томе, зауставила се при углу од $12^{0}$, тј. раније од нормалне лопатице која се зауставила при углу од $14^{0}$ у условима стационарног протока. 